\title{
Comparative Study of the Composition of the Mainstream Smoke of Five Brands Factory-made-cigarettes and Their Counterpart Roll-your-own Tobaccos
}

\author{
A. Marcilla*, M. I. Beltrán, A. Gómez-Siurana, I. Martínez-Castellanos, D. Berenguer
}

Department of Chemical Engineering, University of Alicante, Spain

Copyright $\odot 2018$ by authors, all rights reserved. Authors agree that this article remains permanently open access under the terms of the Creative Commons Attribution License 4.0 International License

\begin{abstract}
A comparative analysis of the mainstream smoke (gas fraction and condensed fraction) obtained from 5 brands of roll-your-own (RYO) tobaccos and the same brand of manufactured cigarettes (MC) commercialized in Spain has been carried out. Both types of tobaccos were smoked using after conditioning under the same conditions and using the same commercial tubes with no vent holes. The average CO yield of the five RYO brands is $27.5 \mathrm{mg} / \mathrm{g}$ of smoked tobacco, whereas for MC tobaccos the average is $19.2 \mathrm{mg} / \mathrm{g}$ of smoked tobacco. Other harmful compounds present in the gas fraction such as aldehydes are also more abundant in RYO tobaccos, while aromatics, paraffins and olefins are more abundant in MC tobaccos. The results show that in general RYO tobaccos also provide higher yields for the compounds analyzed in the condensed fraction than the MC tobaccos of the same brand. The average of nicotine and tar (in $\mathrm{mg} / \mathrm{g}$ smoked tobacco) is 2.42 and 19.92, respectively for the five RYO tobaccos and 1.78 and 14.47 for the MC brands.
\end{abstract}

Keywords RYO Tobacco, MC Tobacco, CO Yield, Nicotine Yield, TPM

\section{Introduction}

To control the harmful effects of tobacco, the World Health Organization [1] works actively to encourage Member States to ratify the Framework Convention on Tobacco Control (FCTC). An international treaty on tobacco control exists which aims to reduce smoking-induced morbidity and mortality by imposing regulations on tobacco products, such as their content, packaging, advertising, marketing, sponsorship, price or taxation and illicit trade. Nevertheless, regulations on $\mathrm{CO}$, nicotine and tar are more severe for manufactured cigarettes (MC) than for roll-your-own (RYO) tobacco [2].

There is a misperception that RYO cigarettes pose less harm to manufactured cigarettes. Nevertheless, there are many studies indicating that such extended thinking is false. Castaño et al. [3] study indicated that this type of tobacco delivers $70 \%$ more nicotine than the law allows in conventional cigarettes and $84 \%$ more tar and carbon monoxide. Laugesen et al. [4] also observed that tar in RYO tobacco smoke was much higher than in MC smoke. The paper type, the tube, filter and vent holes and other design parameters as well as the smoking habits of RYO and MC smokers greatly affect the results obtained [4-7].

Shalab et al. [8] published an interesting paper comparing in vivo the exposure to carcinogens (1-hydroxy-pyrene and total nitrosamines in urine) among RYO and MC smokers. They concluded that RYO tobacco is as toxic as MC tobacco. Moreover, the amount of additives in RYO tobaccos can also be higher than in MC [5]. Nevertheless, most RYO smokers think that RYO tobacco is more natural than the MC tobacco.

At the end of 2012, the European Commission presented a proposal to review the directive on tobacco products. An important point in this proposal is the adding on cigarette and RYO packages a health warning combined picture and text covering $75 \%$ of the package with no promotional elements. Nevertheless, values for $\mathrm{CO}$, tar and nicotine are not included in RYO packages up to now.

In 1998 Darrall and Figgings [9] pointed out that there were no internationally recognized methods to determine the smoke yields in hand-rolled cigarettes. Today, the situation appears similar, probably due to the difficulty in standardizing the different habits and a number of possibilities affecting the results, as already mentioned before. Because of this, the fact is that most consumers ignore the yield of nicotine and tar that this type of tobacco 
may generate. Since 1989 in Canada, tar, nicotine and CO values are shown in the packages of RYO tobacco, something that has not happened in packages in other countries as for example Spanish RYO tobacco where only some brands show values for nicotine.

Moreover, the consumption of RYO tobacco has changed to a large extent. According to the Comisionado para el Mercado de Tabacos (CMT) [10], the consumption of RYO tobacco in Spain has increased at 120\% (market share \% euros) in the last years (2009-2012). This is probably due to its low cost and to the idea that this tobacco is less harmful [5]. Other countries present the contrary tendency, for example, in the United States (2008-2011) the consumption of RYO tobacco has decreased around $75.7 \%$ [11]. This tendency can be observed in other countries like Canada, Great Britain, France, and Australia where the consumption of RYO tobacco has increased may be due to the idea that this tobacco is cheaper than MC tobacco [5].

An increasing number of studies are appearing on RYO tobaccos. Nevertheless, no studies have been found where a complete comparative analysis of the smoke composition (31 compounds in the gaseous fraction and 73 in the particulate matter) of RYO and MC tobaccos is presented. In this work, the differences in the smoke composition when smoking the same brands of RYO and MC tobaccos, smoked under the same conditions, is presented; the same tubes with no ventilation holes in the filter (the most common form of smoking RYO tobacco) and under the same conditioning conditions smoking system and using the same draw resistance.

\section{Materials and Methods}

\subsection{Materials and Experimental Procedure}

Five RYO tobacco brands and the same commercial MC brands were selected. Table 1 shows the brands selected for this study and the tobacco companies. The brands have been renamed with letters from $\mathrm{A}$ to $\mathrm{E}$ in a different order than that shown in Table 1, since the brand is not relevant for this study.

Table 1. Brands of RYO and MC tobaccos studied in this work.

\begin{tabular}{|c|c|}
\hline BRANDS & Tobacco company \\
\hline Winston & JTI \\
\hline Camel & JTI \\
\hline Ducados Rubio & Imperial Tobacco \\
\hline Marlboro & Philip Morris International \\
\hline Chesterfield & Philip Morris International \\
\hline
\end{tabular}

Before carrying out the experiments, all tobacco samples, both RYO and MC tobaccos, were conditioned for at least $48 \mathrm{~h}$ at $22^{\circ} \mathrm{C}$ and $60 \%$ of relative humidity, according to
ISO 3308. Cigarettes (RYO and from MC) were prepared using Mascotte commercial tubes and filters (Mascotte Hulzen X-LONG), without ventilation holes, to eliminate the influence of these variables. These tubes were selected since they more likely correspond to the RYO cigarettes smoked by consumers because the paper used (that also covers the filter) has typically no ventilation holes. The pressure loss in a cigarette has to be below $300 \mathrm{~Pa}$, so, due to the different properties of the tobacco threads, the amount of tobacco per cigarette in RYO and MC brands was different, but in this way, similar draw resistance is guaranteed according to the standard. The cigarettes were smoked in a smoking machine according to the ISO 3308 standard, i.e.: $35 \mathrm{~mL}, 2 \mathrm{~s}$ puffs, every $60 \mathrm{~s}$, until a butt length of $33.2 \mathrm{~mm}$ (filter length $+8 \mathrm{~mm}$, ISO 4387) resulting in a different number of puffs for each tobacco. Table 2 shows the initial tobacco weight in each and the average number of puffs per cigarette. Different burning rates were obtained for the counterparts, especially for brand $\mathrm{D}$, where more than one additional puff was observed for MC tobacco as compared to the same brand of RYO tobacco.

Table 2. Number of puffs, smoked tobacco and TPM obtained for the different MC and RYO tobaccos.

\begin{tabular}{|c|c|c|c|c|}
\hline EXPERIMENT & Puffs & $\begin{array}{c}\text { Tobacco/ } \\
\text { cigarette } \\
\text { (g) }\end{array}$ & $\begin{array}{c}\text { Smoked } \\
\text { tobacco } \\
\text { /cigarette } \\
\text { (g) }\end{array}$ & $\begin{array}{c}\text { TPM } \\
\text { (mg/g } \\
\text { smoked } \\
\text { tobacco) }\end{array}$ \\
\hline A RYO & 9.5 & 0.851 & 0.695 & 19.64 \\
\hline A MC & 9 & 0.826 & 0.629 & 15.08 \\
\hline B RYO & 10 & 0.937 & 0.764 & 19.12 \\
\hline B MC & 10 & 0.854 & 0.616 & 12.41 \\
\hline C RYO & 9 & 0.867 & 0.709 & 18.77 \\
\hline C MC & 9 & 0.836 & 0.627 & 13.56 \\
\hline D RYO & 8.3 & 0.855 & 0.704 & 20.11 \\
\hline D MC & 10 & 0.824 & 0.608 & 14.19 \\
\hline E RYO & 7.5 & 0.645 & 0.551 & 21.97 \\
\hline E MC & 7 & 0.639 & 0.505 & 17.09 \\
\hline
\end{tabular}

As can be seen in Figure 1, the threads of the MC tobaccos are very different from those of the RYO tobaccos despite being the same brand/variety. The morphology of the strands of tobacco and their packing in the cigarette rods may influence the results of the smoking experiments $[12,13]$. MC tobaccos are composed of tobacco cut into small rectangles of around 1-8 $\mathrm{mm}$ and appear to come from the cut leaf. However, RYO tobaccos are composed of thinner and longer strands of tobacco. Among the MC tobaccos there are also differences and for example brand $\mathrm{B}$ has a larger particle size, whereas brand $\mathrm{C}$ is more finely cut. Something similar is observed in RYO tobaccos where $\mathrm{B}$ and $\mathrm{D}$ have finer strands, whereas brand $\mathrm{D}$ has thicker and more heterogeneous strands. It can also be seen that within the same brand, the colour of the tobacco changes, 
which could be related to the part of the leaf of the tobacco from where it comes, to the use of different additives, or other variables of the manufacturing process.

\section{FMC RYO}
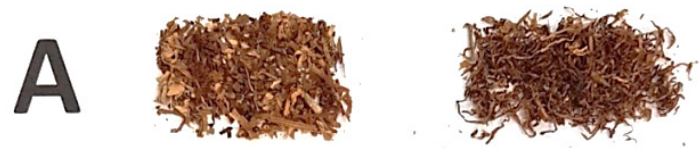

B
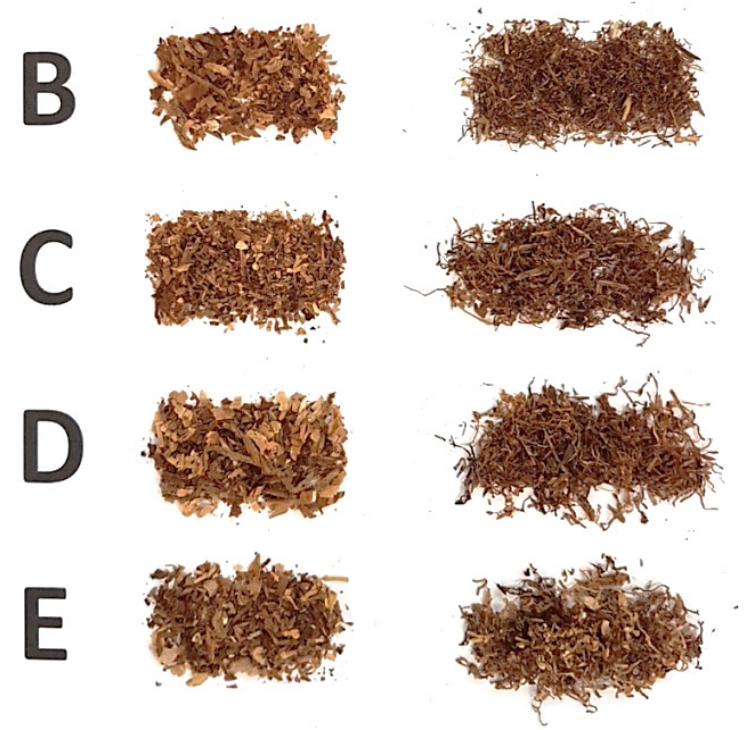

Figure 1. Image of strands of MC and RYO tobaccos

The smoking and sampling process was performed as described elsewhere [14]. The gaseous fraction of tobacco smoke was collected in a Tedlar bag and analyzed by CG/TCD and GC/FID FID in an Agilent 6890N chromatograph with a GS-GASPRO column. The injector temperature was $150^{\circ} \mathrm{C}$, and the $\mathrm{GC}$ oven temperature program was: $35^{\circ} \mathrm{C}$ for $10 \mathrm{~min}, 5^{\circ} \mathrm{C} / \mathrm{min}$ up to $100^{\circ} \mathrm{C}$, $15^{\circ} \mathrm{C} / \mathrm{min}$ up to $200^{\circ} \mathrm{C}$ and $10 \mathrm{~min}$ at the final temperature. Helium was used as carrier gas $(2 \mathrm{~mL} / \mathrm{min})$ and the volume of sample injected was $150 \mu \mathrm{L}$. The total particulate matter (TPM) condensed in the trap located before the Tedlar gas was analyzed by GC/MS after extracting with isopropanol following the ISO4387 standard in an Agilent $6890 \mathrm{~N}$ chromatograph with a HP-5-MS column. The injector temperature was $250^{\circ} \mathrm{C}$ and the $\mathrm{GC}$ oven program used in this case was: initial temperature of $40^{\circ} \mathrm{C}$ for $5 \mathrm{~min}$, ramp of $12^{\circ} \mathrm{C} / \mathrm{min}$ up to $320^{\circ} \mathrm{C}$ and $25 \mathrm{~min}$ at the final temperature. The carrier gas was helium with a flow rate of $2 \mathrm{~mL} / \mathrm{min}$ and the volume of sample injected was $1 \mu \mathrm{L}$. The assignation of peaks to compounds was done by comparison with the Wiley MS library. In this work, 31 compounds were analyzed in the gaseous fraction collected in the Tedlar bag and 73 compounds were analyzed in the TPM.

\section{Results and Discussion}

\subsection{Preliminary Analysis}

Table 2 shows the number of puffs, the initial amount of tobacco per cigarette, the amount of smoked tobacco per cigarette and the TPM. As indicated in the previous section in order to obtain more homogenous cigarettes, the tubes were completely filled manually attempting to have similar levels of tobacco packing and a similar draw resistance at the beginning of the run.

Due to the heterogeneity of tobacco and the differences between the fibers, which varies substantially both when changing the tobacco brand and the type of tobacco (RYO or $\mathrm{MC}$ ), the average amount of tobacco used with each cigarette brand is different. As can be seen in Table 2, around 0.8-0.9 grams of tobacco were used per cigarette, except in brand $\mathrm{E}$ that had less tobacco, 0.64 grams per cigarette due to the morphology of the fibers. The amount of tobacco per cigarette is higher for the RYO brands than MC. Table 2 also shows that the amount of smoked tobacco per cigarette is also higher in the case of RYO tobaccos, and despite being expressed in a grams-per-smoked tobacco basis, TPM is much higher for the RYO tobaccos. The amount of tobacco smoked for RYO tobacco ranges from 81.7 to $85.5 \%$, while in the case of MC tobacco the amount of tobacco smoked for the different brands shows a larger dispersion (72-79\%), which may be a consequence of the higher homogeneity of the RYO fibers. In general, according to Table 2 , it could be said that a greater amount of initial tobacco implies a greater amount of smoked tobacco and consequently a higher yield of TPM. In this work TPM, as well as all the compounds analysed, refers to the amount of tobacco smoked instead being expressed in a cigarette basis which is also quite common.

\subsection{Analysis of the Gaseous Fraction}

European legislation controls tar, $\mathrm{CO}$ and nicotine [15]. Water, $\mathrm{CO}_{2}$ and $\mathrm{CO}$ are the major individual components of the mainstream tobacco smoke. Moreover, $\mathrm{CO}$ is considered a dangerous blood poison and tobacco smoke is an important cause of $\mathrm{CO}$ exposure [16]. The formation of $\mathrm{CO}$ depends on different variables such as filter size and type, ventilation, paper and tobacco blends, draw resistance, etc. [17]. Table 3 shows the $\mathrm{CO}$ yields obtained expressed in $\mathrm{mg} / \mathrm{g}$ of smoked tobacco for the RYO and MC tobaccos. It can be observed that all RYO tobaccos show higher values of $\mathrm{CO}$ than those provided by the same MC brand tobaccos when smoked under the same conditions. If the $\mathrm{CO}$ yield obtained is calculated as $\mathrm{mg} /$ cigarette, all RYO tobacco brands have values higher than those permitted by European legislation that establishes a carbon monoxide limit of $10 \mathrm{mg} /$ cigarette nicotine [15]. However, RYO B and $\mathrm{C}$ brands showed more than double the allowed values. In these conditions, only B-MC and D-MC comply with 
the current regulations, although in general, all $\mathrm{MC}$ tobaccos show values close to the standard.

Table 3 shows the compounds identified in the gaseous fraction. Figure 1 shows the amount of "total gases" calculated as the sum of all components excluding $\mathrm{CO}$ and $\mathrm{CO}_{2}$. Despite the fact that RYO tobaccos yield larger amounts of $\mathrm{CO}$ than $\mathrm{MC}$, both types of tobacco and all brands yield similar amounts of $\mathrm{CO}_{2}$ (Table 3). It is worth mentioning the case of brand $\mathrm{E}$, which presents a yield of $\mathrm{CO}$ and $\mathrm{CO}_{2}$ higher than to the rest of brands, even though the cigarettes of this brand (E-RYO and E-MC) are those that had the smallest initial amount of tobacco. Table 3 shows that the compounds generated in larger amounts in this fraction are methane and acetaldehyde showing an abundance of more than twice that of ethane. It should be noted that the two main compounds are generated in different proportions; methane is the more abundant compound for all MC, with values between $1.62-1.76 \mathrm{mg} / \mathrm{g}$ of smoked tobacco, for A-RYO and C-RYO brands respectively. Acetaldehyde is generated in greater proportion for three RYO B, D and E brands. In the case of B-RYO tobacco, a yield in acetaldehyde much higher than the rest of tobaccos $(2.61 \mathrm{mg} / \mathrm{g}$ smoked tobacco) was obtained. Acetaldehyde is mentioned in the Hoffmann list and is a hazardous smoke component.

In general $\mathrm{MC}$ tobaccos generate a higher total gas fraction yield than the corresponding RYO tobaccos (Figure 2), except in the case of brand B that presents a yield of gases higher than that of any of the MC tobaccos.
This effect may be due to the fact that B-RYO has the highest amount of tobacco per cigarette. This amount is also much higher than the initial amount of tobacco used for the same brand in MC tobacco, while the other brands present similar initial amounts of tobacco for the RYO and MC tobaccos. MC tobaccos show a narrow range of gas yield, between 5.72 and $6.51 \mathrm{mg} / \mathrm{g}$ smoked tobacco, while the gas yield range present for RYO tobaccos is larger, i.e.: between 5.00 to $6.97 \mathrm{mg} / \mathrm{g}$ smoked tobacco.

In order to facilitate the analysis, the compounds of the gas fraction were grouped into in chemical families, as described elsewhere [14, 18]. The chemical families considered were paraffins, olefins, aromatics, aldehydes and the family "others" which includes compounds containing heteroatoms such as hydrogen cyanide, chloromethane or methanethiol. Figure 3 shows the yields of the different chemical families appearing in the gaseous fraction of the mainstream smoke. As can be seen, the more abundant compounds are paraffins followed by olefins and aldehydes. Aromatics and other compounds appear to a noticeably lesser extent. The maximum values for paraffins, olefins, aromatics and "others" were obtained in the gases evolved when MC tobaccos were smoked, whilst aldehydes are more abundant for RYO tobaccos (except C-RYO). It is necessary to emphasize the behavior of B-RYO which shows a much higher yield of aldehydes than the other brands. This effect is directly caused by the high yield of acetaldehyde that this brand generates $(2.61$ $\mathrm{mg} / \mathrm{g}$ smoked tobacco).

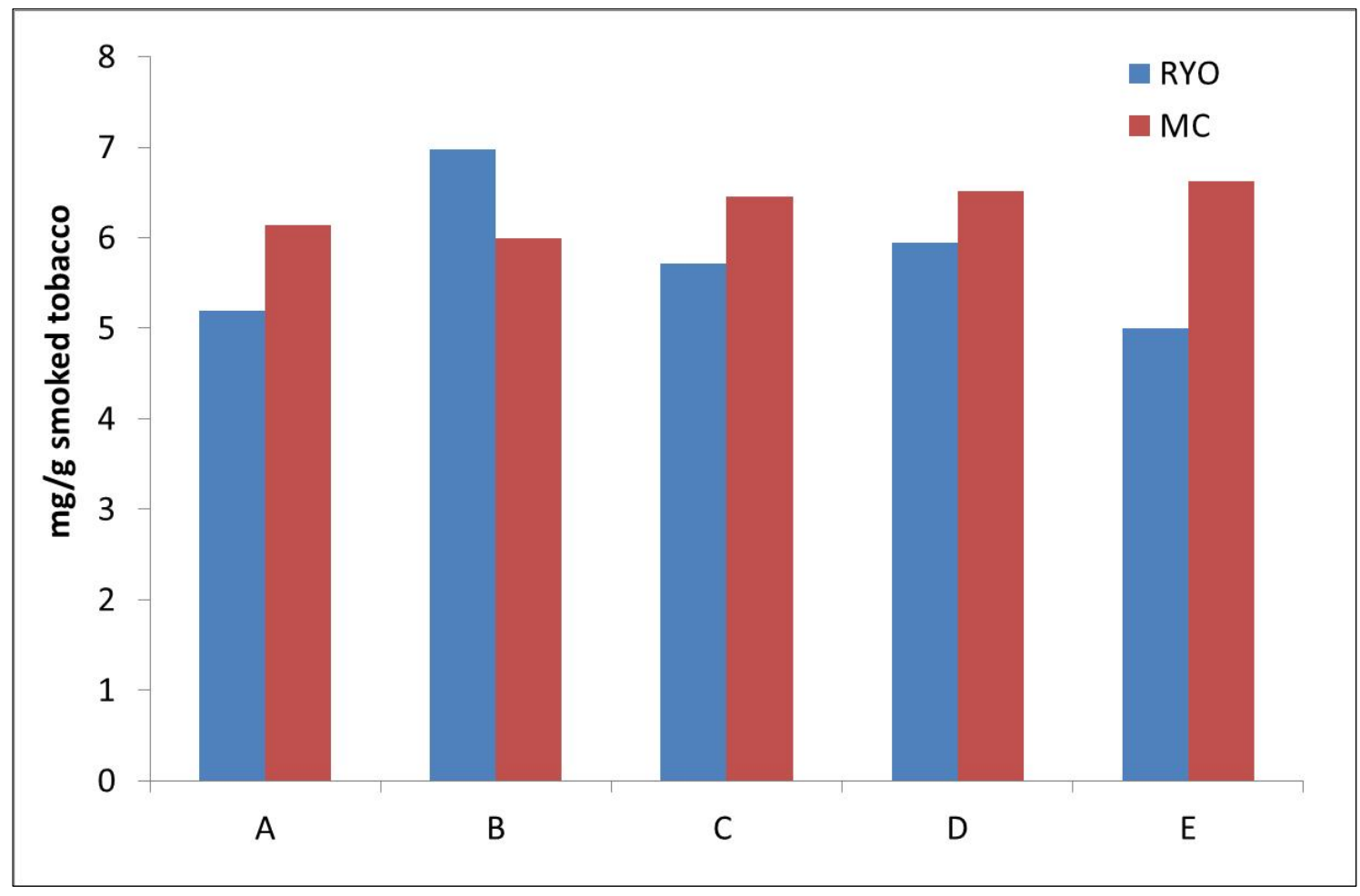

Figure 2. Total yield of gasses ( $\mathrm{mg} / \mathrm{g}$ smoked tobacco) for MC and RYO tobaccos 


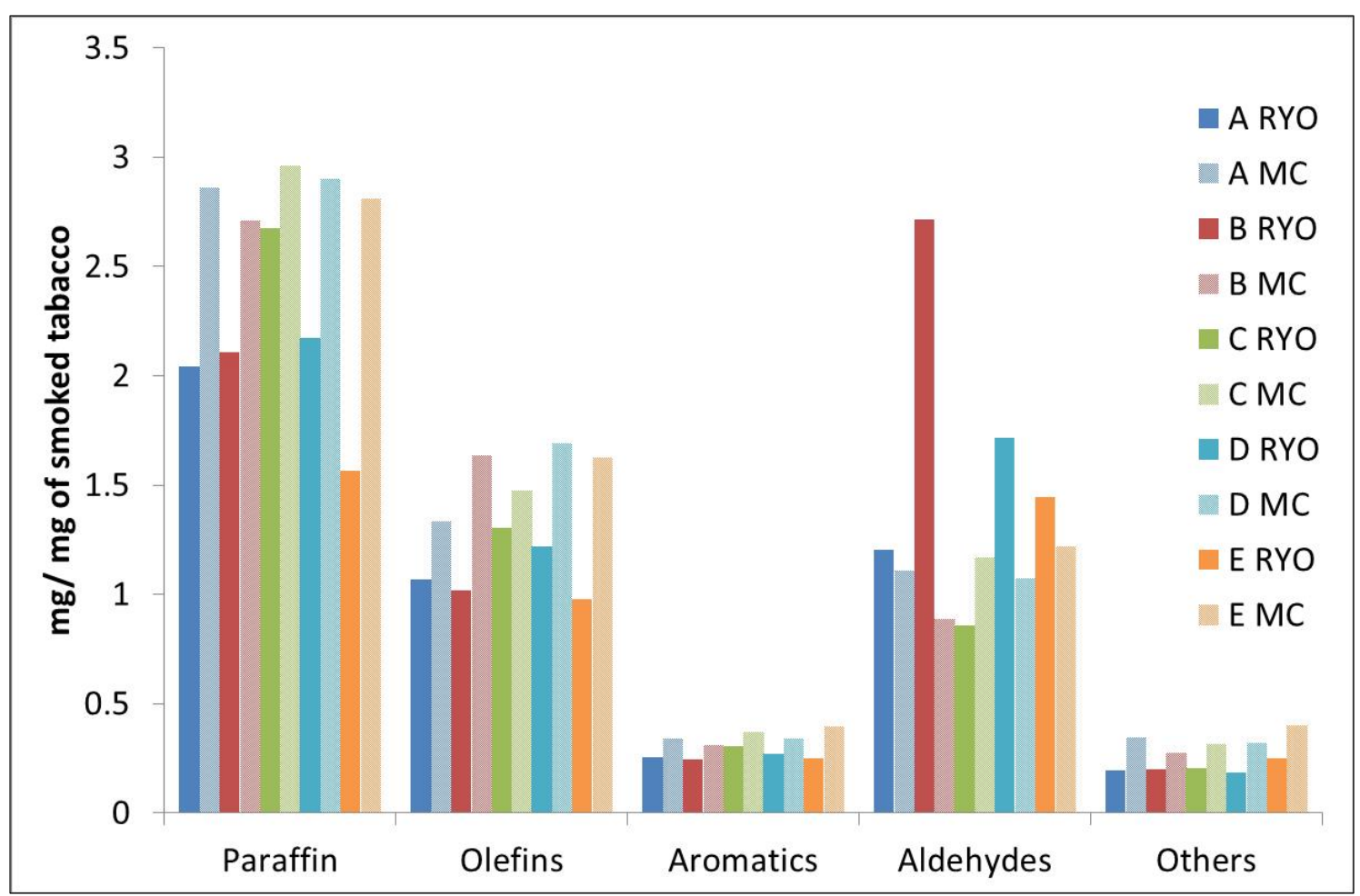

Figure 3. Yields of the different chemical families obtained in the gaseous fraction for MC and RYO tobaccos. 
Table 3. Yields in $\mathrm{mg} / \mathrm{g}$ smoked tobacco of compounds analyzed in the gaseous fraction for MC and RYO tobaccos

\begin{tabular}{|c|c|c|c|c|c|c|c|c|c|c|}
\hline mg/g smoked tobacco & A RYO & A MC & B RYO & B MC & C RYO & C MC & D RYO & D MC & E RYO & E MC \\
\hline $\mathrm{CO}$ & 24 & 19 & 27 & 16 & 27 & 19 & 28 & 18 & 32 & 24 \\
\hline $\mathrm{CO}_{2}$ & 115 & 109 & 111 & 113 & 115 & 126 & 112 & 119 & 129 & 130 \\
\hline Methane & 1.2 & 1.6 & 1.2 & 1.6 & 1.6 & 1.8 & 1.2 & 1.7 & 0.91 & 1.7 \\
\hline Ethane & 0.50 & 0.63 & 0.52 & 0.64 & 0.64 & 0.72 & 0.53 & 0.70 & 0.38 & 0.65 \\
\hline Ethylene & 0.26 & 0.37 & 0.27 & 0.39 & 0.33 & 0.40 & 0.30 & 0.42 & 0.27 & 0.44 \\
\hline Ethyne & 0.03 & 0.05 & 0.03 & 0.06 & 0.04 & 0.06 & 0.04 & 0.06 & 0.04 & 0.07 \\
\hline Propane & 0.23 & 0.28 & 0.24 & 0.29 & 0.29 & 0.32 & 0.25 & 0.31 & 0.18 & 0.29 \\
\hline Propene & 0.26 & 0.33 & 0.26 & 0.35 & 0.32 & 0.37 & 0.28 & 0.38 & 0.24 & 0.37 \\
\hline Iso-butane & 0.02 & 0.03 & 0.02 & 0.04 & 0.03 & 0.03 & 0.02 & 0.05 & 0.02 & 0.03 \\
\hline Chloromethane & 0.05 & 0.08 & 0.07 & 0.07 & 0.04 & 0.09 & 0.04 & 0.08 & 0.08 & 0.11 \\
\hline Butane & 0.07 & 0.08 & 0.07 & 0.09 & 0.09 & 0.10 & 0.08 & 0.09 & 0.05 & 0.08 \\
\hline 1-Butene & 0.06 & 0.08 & 0.06 & 0.08 & 0.08 & 0.09 & 0.07 & 0.09 & 0.06 & 0.09 \\
\hline 1,2-Propadiene & 0.01 & 0.02 & 0.01 & 0.02 & 0.01 & 0.02 & 0.02 & 0.02 & 0.02 & 0.03 \\
\hline 1,3-Butadiene & 0.02 & 0.03 & 0.02 & 0.03 & 0.03 & 0.03 & 0.02 & 0.03 & 0.02 & 0.03 \\
\hline Isobutene & 0.06 & 0.05 & 0.06 & 0.05 & 0.07 & 0.06 & 0.06 & 0.06 & 0.06 & 0.06 \\
\hline cis-2-Butene & 0.05 & 0.08 & 0.04 & 0.08 & 0.06 & 0.09 & 0.03 & 0.09 & 0.04 & 0.08 \\
\hline Pentane & 0.02 & 0.01 & 0.02 & 0.01 & 0.03 & 0.01 & 0.02 & 0.01 & 0.02 & 0.01 \\
\hline Methanethiol & 0.02 & 0.03 & 0.03 & 0.03 & 0.04 & 0.03 & 0.02 & 0.03 & 0.03 & 0.04 \\
\hline Hydrogen cyanide & 0.01 & 0.02 & 0.02 & 0.02 & 0.02 & 0.02 & 0.02 & 0.02 & 0.01 & 0.02 \\
\hline 1-Pentene & 0.02 & 0.02 & 0.01 & 0.02 & 0.02 & 0.02 & 0.01 & 0.03 & 0.02 & 0.02 \\
\hline Furan & 0.02 & 0.03 & 0.02 & 0.03 & 0.03 & 0.03 & 0.03 & 0.03 & 0.02 & 0.03 \\
\hline Isoprene & 0.31 & 0.44 & 0.26 & 0.57 & 0.37 & 0.39 & 0.40 & 0.56 & 0.26 & 0.49 \\
\hline Hexane & 0.02 & 0.02 & 0.01 & 0.03 & 0.03 & 0.02 & 0.02 & 0.03 & 0.01 & 0.02 \\
\hline 1-Hexene & 0.02 & 0.02 & 0.02 & 0.02 & 0.02 & 0.02 & 0.02 & 0.02 & 0.02 & 0.02 \\
\hline Benzene & 0.17 & 0.21 & 0.16 & 0.21 & 0.20 & 0.25 & 0.19 & 0.23 & 0.17 & 0.28 \\
\hline Acetaldehyde & 1.1 & 0.75 & 2.6 & 0.75 & 0.74 & 1.1 & 1.6 & 0.96 & 1.3 & 1.1 \\
\hline Acrolein & 0.05 & 0.04 & 0.04 & 0.05 & 0.05 & 0.04 & 0.03 & 0.04 & 0.05 & 0.07 \\
\hline Propionaldehyde & 0.04 & 0.04 & 0.04 & 0.05 & 0.05 & 0.05 & 0.04 & 0.05 & 0.04 & 0.06 \\
\hline Acetonitrile & 0.07 & 0.12 & 0.06 & 0.11 & 0.07 & 0.12 & 0.07 & 0.13 & 0.09 & 0.15 \\
\hline Toluene & 0.04 & 0.05 & 0.04 & 0.05 & 0.05 & 0.06 & 0.04 & 0.06 & 0.04 & 0.06 \\
\hline 2,5-Dimethylfuran & 0.02 & 0.02 & 0.02 & 0.03 & 0.03 & 0.03 & 0.01 & 0.03 & 0.01 & 0.03 \\
\hline Crotonaldehyde & 0.01 & 0.01 & 0.01 & 0.01 & 0.01 & 0.01 & 0.01 & 0.01 & 0.01 & 0.01 \\
\hline Isobutyraldehyde & 0.02 & 0.01 & 0.03 & 0.01 & 0.01 & 0.01 & 0.03 & 0.02 & 0.03 & 0.01 \\
\hline Total without $\mathrm{CO}$ and $\mathrm{CO}_{2}$ & 5.2 & 5.7 & 7.0 & 6.0 & 5.7 & 6.5 & 6.0 & 6.5 & 5.0 & 6.6 \\
\hline Total with $\mathrm{CO}$ and $\mathrm{CO}_{2}$ & 144 & 134 & 145 & 135 & 149 & 152 & 146 & 144 & 166 & 160 \\
\hline
\end{tabular}


Table 4. Yields of compounds analyzed in TPM in $\mathrm{mg} / \mathrm{g}$ smoked tobacco for MC and RYO tobaccos

\begin{tabular}{|c|c|c|c|c|c|c|c|c|c|c|}
\hline$\mu \mathrm{g} / \mathrm{g}$ smoked tobacco & A RYO & A MC & B RYO & B MC & C RYO & $\mathrm{C}$ MC & D RYO & D MC & E RYO & E MC \\
\hline Pyridine, 4-methyl- & 2.81 & 2.40 & 1.05 & 1.55 & 0.00 & 1.50 & 2.76 & 1.90 & 1.91 & 2.58 \\
\hline Pyrazine, methyl- & 1.59 & 1.91 & 0.74 & 1.11 & 0.00 & 1.14 & 0.00 & 1.08 & 1.64 & 1.95 \\
\hline Furfural & 6.75 & 11.29 & 2.95 & 7.20 & 0.00 & 7.64 & 0.00 & 5.82 & 5.62 & 13.83 \\
\hline 2-Pentanone, 4-hydroxy-4-methyl- & 1.10 & 9.83 & 2.75 & 5.34 & 4.14 & 5.78 & 0.00 & 6.04 & 0.58 & 11.26 \\
\hline Ethanol, 2-(1-methylethoxy)- & 7.12 & 7.30 & 4.34 & 7.31 & 6.36 & 5.98 & 1.59 & 5.78 & 0.00 & 8.32 \\
\hline 2-Furanmethanol & 3.27 & 0.00 & 0.00 & 0.00 & 0.00 & 0.00 & 0.00 & 0.00 & 0.00 & 0.00 \\
\hline Pyridine, 3-methyl- & 1.65 & 3.75 & 1.31 & 2.10 & 1.95 & 2.42 & 3.35 & 2.20 & 3.22 & 4.37 \\
\hline 2-Propanone, 1-(acetyloxy)- & 1.98 & 4.16 & 0.86 & 2.21 & 1.74 & 2.95 & 1.52 & 2.35 & 1.24 & 5.14 \\
\hline 4-Cyclopentene-1,3-dione & 4.26 & 1.94 & 2.66 & 1.70 & 5.44 & 1.26 & 4.42 & 0.91 & 1.34 & 4.47 \\
\hline Styrene & 2.13 & 1.66 & 1.10 & 1.51 & 1.35 & 1.83 & 1.08 & 1.32 & 1.13 & 2.19 \\
\hline 2-Cyclopenten-1-one, 2-methyl- & 7.44 & 7.82 & 2.43 & 4.62 & 4.61 & 5.77 & 5.47 & 5.00 & 5.03 & 7.70 \\
\hline 2-Acetylfuran & 1.61 & 3.78 & 1.75 & 2.22 & 2.82 & 2.72 & 2.79 & 2.25 & 2.44 & 3.72 \\
\hline $2(5 \mathrm{H})$-furanone & 1.24 & 1.10 & 1.65 & 0.67 & 2.22 & 0.70 & 1.78 & 0.57 & 1.67 & 1.40 \\
\hline Pyrazine, 2,3-dimethyl- & 0.00 & 1.31 & 0.00 & 0.71 & 0.00 & 0.53 & 0.00 & 0.66 & 0.00 & 1.70 \\
\hline 2-Hydroxycyclopent-2-en-1-one & 3.81 & 4.65 & 1.62 & 3.28 & 3.19 & 2.85 & 0.80 & 3.49 & 0.98 & 5.88 \\
\hline Pyridine, 3,5-dimethyl- & 0.00 & 2.31 & 1.35 & 1.26 & 2.02 & 1.70 & 2.35 & 1.27 & 2.01 & 2.47 \\
\hline 2,5-Dimethyl-2-cyclopentenone & 3.07 & 2.41 & 0.86 & 1.89 & 1.56 & 1.82 & 1.89 & 1.61 & 1.50 & 2.37 \\
\hline 2(3H)-furanone, 5-methyl- & 0.00 & 1.29 & 0.00 & 0.87 & 0.00 & 0.95 & 0.00 & 0.84 & 0.00 & 1.50 \\
\hline Ethanol, 2-butoxy- & 3.83 & 13.03 & 0.00 & 8.73 & 0.00 & 11.95 & 0.00 & 8.70 & 0.00 & 14.57 \\
\hline Benzaldehyde & 3.32 & 4.02 & 0.93 & 1.76 & 1.79 & 2.94 & 1.93 & 1.26 & 2.02 & 5.24 \\
\hline Furfural, 5-methyl- & 1.46 & 9.69 & 2.77 & 5.87 & 5.59 & 7.40 & 4.12 & 6.48 & 4.41 & 11.00 \\
\hline Pyridine, 3-ethenyl- & 1.90 & 1.12 & 0.59 & 1.65 & 1.63 & 1.18 & 1.93 & 1.17 & 1.72 & 1.22 \\
\hline 2(5H)-Furanone, 3-methyl- & 0.60 & 0.00 & 1.29 & 0.00 & 1.62 & 0.00 & 0.93 & 0.00 & 0.91 & 2.57 \\
\hline Phenol & 19.38 & 28.15 & 14.28 & 17.03 & 16.40 & 19.08 & 17.69 & 18.47 & 14.17 & 23.78 \\
\hline 2-isopropylfuran & 3.46 & 3.17 & 3.71 & 6.08 & 4.41 & 6.26 & 3.73 & 5.73 & 3.09 & 8.70 \\
\hline 2-Cyclopenten-1-one, 2-hydroxy-3-methyl- & 0.00 & 16.09 & 5.93 & 9.12 & 7.73 & 12.19 & 7.03 & 10.44 & 4.48 & 15.08 \\
\hline Limonene & 25.13 & 13.58 & 8.93 & 9.03 & 6.01 & 8.48 & 6.93 & 8.60 & 7.14 & 15.58 \\
\hline
\end{tabular}




\begin{tabular}{|c|c|c|c|c|c|c|c|c|c|c|}
\hline 2,3-Dimethyl-2-cyclopenten-1-one & 7.00 & 5.75 & 2.52 & 3.31 & 4.81 & 4.10 & 4.38 & 3.53 & 3.32 & 4.60 \\
\hline Indeno & 3.59 & 1.83 & 0.00 & 1.19 & 1.31 & 1.09 & 1.26 & 1.61 & 0.89 & 1.73 \\
\hline o-Cresol & 9.34 & 17.83 & 8.49 & 12.88 & 11.21 & 14.57 & 9.16 & 12.77 & 9.34 & 17.95 \\
\hline 2-Acetylpyrrole & 5.06 & 1.93 & 4.11 & 0.71 & 0.00 & 0.00 & 0.00 & 0.00 & 0.00 & 2.04 \\
\hline Phenol, 4-methoxy- & 0.00 & 1.89 & 0.00 & 0.88 & 0.00 & 1.64 & 0.00 & 0.00 & 0.00 & 1.97 \\
\hline Ethanone, 1-phenyl- & 3.09 & 0.00 & 0.00 & 1.53 & 0.00 & 0.94 & 0.00 & 2.40 & 0.00 & 1.30 \\
\hline 3-Ethylcyclopent-2-en-1-one & 0.00 & 3.83 & 1.83 & 2.74 & 3.02 & 3.16 & 2.95 & 3.15 & 2.53 & 3.80 \\
\hline p-Cresol & 17.09 & 27.05 & 16.51 & 17.47 & 19.31 & 21.42 & 17.15 & 19.30 & 17.63 & 24.80 \\
\hline 2 ethyl tiophene & 0.00 & 3.34 & 5.64 & 1.33 & 3.54 & 2.68 & 1.45 & 1.93 & 2.38 & 2.90 \\
\hline Phenol, 2-methoxy- & 6.42 & 8.39 & 4.14 & 6.57 & 6.18 & 7.01 & 6.28 & 6.65 & 6.15 & 8.75 \\
\hline 2-Propanamine & 3.46 & 7.68 & 5.41 & 5.99 & 5.09 & 6.50 & 0.00 & 6.74 & 0.00 & 9.74 \\
\hline 3-Ethyl-2-hydroxy-2-cyclopenten-1-one & 0.00 & 7.73 & 9.32 & 5.71 & 12.48 & 6.85 & 12.33 & 6.90 & 8.62 & 9.50 \\
\hline Benzeneacetonitrile & 10.23 & 0.00 & 0.00 & 0.00 & 0.00 & 0.00 & 0.00 & 0.00 & 0.00 & 0.00 \\
\hline $\begin{array}{l}\text { 2,3-Dihydro-3,5-dihydroxy-6-methyl-4H-pyran- } \\
\text { 4-one }\end{array}$ & 83.02 & 25.11 & 12.32 & 24.96 & 22.89 & 23.39 & 5.70 & 29.04 & 4.13 & 24.22 \\
\hline Phenol, 2,4-dimethyl- & 14.14 & 5.53 & 0.00 & 5.83 & 7.67 & 4.91 & 0.00 & 7.06 & 0.00 & 4.72 \\
\hline Phenol, 4-ethyl- & 16.64 & 4.42 & 1.64 & 2.29 & 7.51 & 3.23 & 4.05 & 2.77 & 6.32 & 3.77 \\
\hline Naphthalene & 3.29 & 2.82 & 3.78 & 4.17 & 11.64 & 3.83 & 15.11 & 5.08 & 12.56 & 5.77 \\
\hline Ethanone, 1-(3-methylphenyl)- & 0.00 & 3.14 & 0.00 & 5.06 & 0.00 & 6.14 & 0.00 & 5.46 & 0.00 & 7.66 \\
\hline p-cresol 2 methoxy & 2.17 & 2.33 & 0.00 & 6.48 & 0.00 & 8.14 & 0.00 & 6.57 & 0.00 & 2.67 \\
\hline 2,3-Dihydro-benzofuran & 20.27 & 10.60 & 12.02 & 6.16 & 9.80 & 9.18 & 11.06 & 8.09 & 10.20 & 8.24 \\
\hline 2-furancarboxaldehyde, 5-(hyd roxymethyl)- & 31.68 & 0.00 & 0.00 & 0.00 & 13.14 & 0.00 & 0.00 & 0.00 & 0.00 & 0.00 \\
\hline 1H-Inden-1-one, 2,3-dihydro- & 20.93 & 11.26 & 2.44 & 7.54 & 7.29 & 8.89 & 3.48 & 9.77 & 2.67 & 10.06 \\
\hline Hydroquinone & 53.38 & 50.83 & 48.80 & 39.22 & 91.30 & 44.05 & 52.85 & 48.56 & 27.28 & 41.94 \\
\hline 1H-Indole & 60.83 & 31.54 & 57.25 & 16.13 & 43.83 & 27.56 & 44.37 & 24.60 & 43.41 & 26.82 \\
\hline 4-vinyl-2-methoxy-phenol & 16.78 & 9.14 & 5.90 & 7.62 & 4.54 & 9.04 & 6.87 & 7.02 & 5.75 & 10.86 \\
\hline Nicotine & 2544.53 & 1874.48 & 2345.43 & 1547.07 & 2087.98 & 1676.13 & 2354.43 & 1808.10 & 2742.77 & 2009.40 \\
\hline 1H-Indole, 3-methyl- & 9.51 & 6.65 & 8.26 & 7.38 & 6.02 & 8.83 & 4.52 & 8.30 & 10.22 & 5.75 \\
\hline Myosmine & 15.91 & 20.31 & 16.88 & 18.52 & 12.72 & 15.88 & 11.58 & 16.13 & 16.28 & 20.19 \\
\hline
\end{tabular}




\begin{tabular}{|c|c|c|c|c|c|c|c|c|c|c|}
\hline Phenol, 2-methoxy-4-(2-propenyl)- & 8.65 & 14.81 & 7.41 & 9.20 & 4.03 & 12.35 & 3.15 & 13.94 & 5.66 & 13.37 \\
\hline Nicotyrine & 5.73 & 6.77 & 11.07 & 7.21 & 12.40 & 6.19 & 7.59 & 7.61 & 13.25 & 8.77 \\
\hline Norsolanadiona & 13.85 & 11.58 & 14.67 & 6.68 & 13.74 & 10.49 & 11.58 & 9.96 & 17.64 & 10.08 \\
\hline 2,3'-Bipyridine & 14.23 & 12.45 & 14.37 & 7.18 & 15.55 & 11.95 & 15.25 & 12.37 & 18.61 & 7.85 \\
\hline Megastigmatrienone & 9.42 & 6.64 & 7.31 & 7.55 & 11.95 & 8.93 & 9.16 & 8.22 & 9.52 & 8.49 \\
\hline N-propyl- nornicotine & 10.40 & 9.04 & 6.03 & 6.47 & 12.74 & 6.64 & 8.72 & 11.47 & 9.44 & 8.88 \\
\hline Cotinine & 17.53 & 19.66 & 23.02 & 15.59 & 25.90 & 18.85 & 33.32 & 21.53 & 30.26 & 19.93 \\
\hline 5-Tetradecene & 12.71 & 9.00 & 10.28 & 7.30 & 9.55 & 8.04 & 9.59 & 8.38 & 9.61 & 9.25 \\
\hline N(b)-formylnornicotine & 20.60 & 11.86 & 18.10 & 12.04 & 15.83 & 12.95 & 19.57 & 20.76 & 24.03 & 14.51 \\
\hline Neophytadiene & 198.37 & 141.63 & 159.92 & 133.01 & 173.77 & 113.47 & 160.92 & 167.06 & 181.44 & 135.56 \\
\hline Farnesol & 15.25 & 11.55 & 18.10 & 13.15 & 21.87 & 7.21 & 28.31 & 8.63 & 11.00 & 10.73 \\
\hline Hexadecanoic acid, ethyl ester & 24.14 & 0.00 & 11.70 & 0.00 & 12.92 & 0.00 & 13.99 & 0.00 & 5.61 & 0.00 \\
\hline Citric acid, tributyl ester, & 6.63 & 0.00 & 16.67 & 0.00 & 20.50 & 0.00 & 0.00 & 0.00 & 19.18 & 0.00 \\
\hline 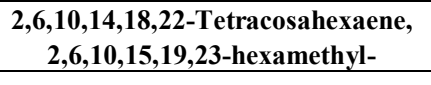 & 19.83 & 17.15 & 14.75 & 14.85 & 10.05 & 12.97 & 9.74 & 14.62 & 14.60 & 13.22 \\
\hline Heptacosane & 30.12 & 21.62 & 38.41 & 18.17 & 30.30 & 19.74 & 31.84 & 31.51 & 24.20 & 29.01 \\
\hline Triacontane & 40.28 & 18.91 & 52.73 & 12.01 & 53.36 & 16.28 & 38.30 & 27.31 & 45.31 & 18.73 \\
\hline Octadecane & 83.83 & 46.09 & 109.60 & 33.16 & 109.02 & 41.00 & 74.37 & 48.64 & 82.61 & 41.18 \\
\hline Tocopherol & 77.05 & 54.25 & 111.51 & 42.64 & 88.21 & 41.39 & 48.73 & 69.87 & 88.24 & 53.00 \\
\hline
\end{tabular}




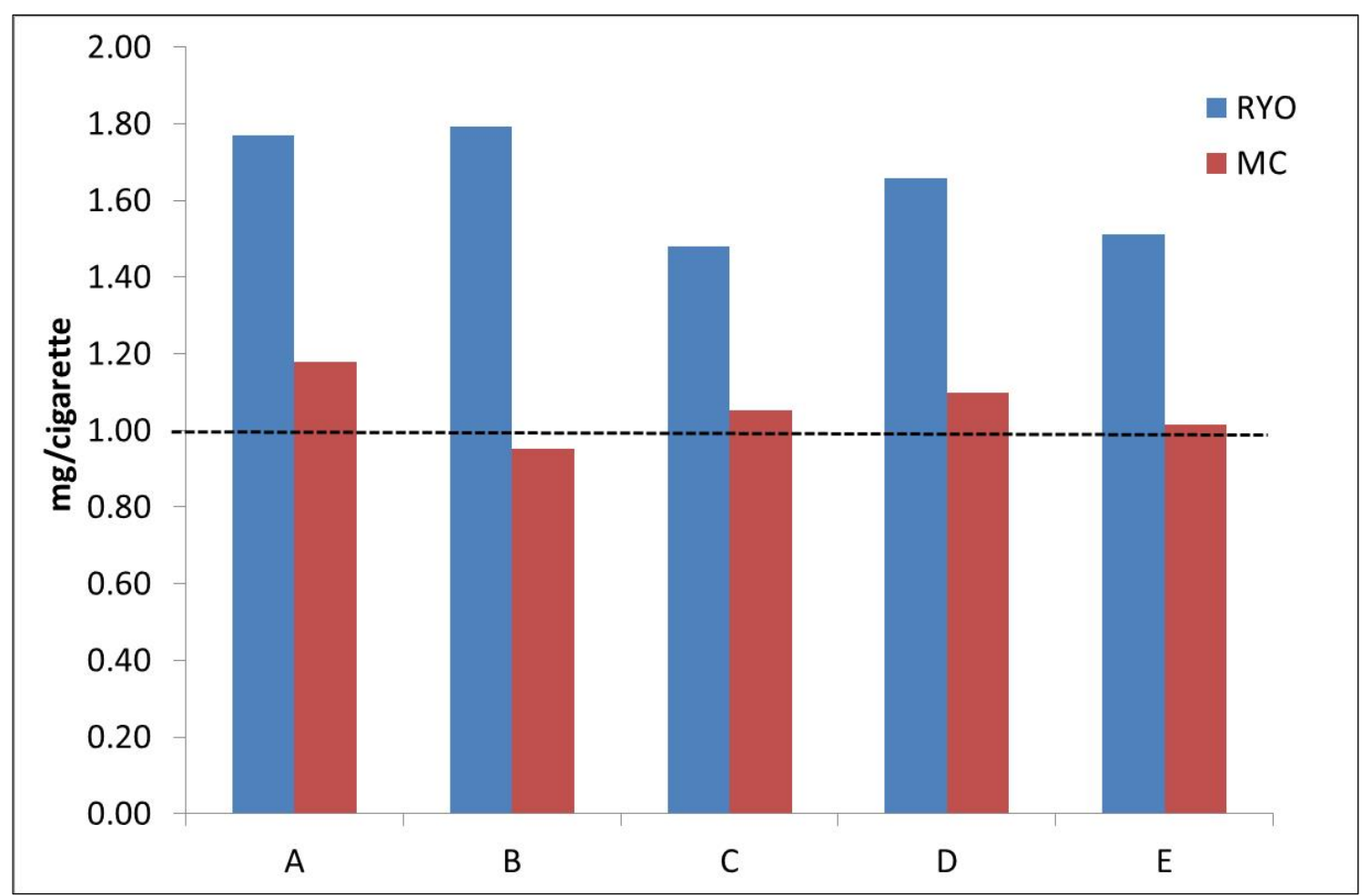

Figure 4. Nicotine yields (mg/cigarette) for MC and RYO tobaccos

\subsection{Particulate Matter}

The yields of all the compounds identified in the condensed fraction are listed in Table 4, arranged according to their retention time. Nicotine is the main reason for smoking because it is that responsible for tobacco addiction and apart from water, is the main component in the condensed fraction of mainstream tobacco smoke. As was observed for carbon monoxide, yields of nicotine for all RYO tobaccos are higher than those obtained in the $\mathrm{MC}$ tobaccos. Nicotine yields for RYO tobaccos range from $2.1-2.7 \mathrm{mg} / \mathrm{g}$ smoked tobacco. For MC tobaccos the nicotine varies from $1.5-2 \mathrm{mg} / \mathrm{g}$ smoked tobacco. As already mentioned, nicotine is regulated, together with tar and $\mathrm{CO}$, by European legislation which limits a maximum value of $1 \mathrm{mg} /$ cigarette [15]. Figure 4 shows the nicotine obtained for the different brands expressed in $\mathrm{mg} /$ cigarette. This Figure permits us to observe that the nicotine obtained when RYO and MC tobaccos are smoked under the same conditions (tubes, filters and smoking regime) described in this work does not comply with the regulations for more of the RYO brands. Only B-MC is within the limits. As can be seen, the larger values of nicotine are for A-RYO and B-RYO tobacco, coinciding with the fact that these brands contain more initial tobacco, and the amount of smoked tobacco was also higher. However, brand E, containing much less initial/smoked tobacco, is not the brand that shows lower yields of nicotine. In fact, as seen in Table 4, brand $\mathrm{E}$ is the one providing the highest yields of nicotine on a per-gram of tobacco smoked basis.

Regarding the other components of the condensed fraction, neophytadiene is after nicotine the more abundant compound, both for RYO and MC tobaccos, and higher yields are obtained when smoking RYO tobaccos, except for brand D. Other compounds with an important yield are octadecene, tocopherol, hydroquinone and $1 \mathrm{H}$-Indole. Moreover, as in the case of neophytadiene, RYO smoke presents a larger amount of these compounds than the corresponding MC brands.

As in the case of the gas fraction, the compounds in TPM have been grouped by families, according to their chemical functionality. The families considered are the following: pyridines, carbonyls, phenolic, epoxies, aliphatics and polyaromatic hydrocarbons (PAHs). The pyridine group does not include nicotine because its yield is as high as the sum of all the other compounds of the family.

Figure 5 shows the yields of the different families expressed in $\mathrm{mg} / \mathrm{g}$ of smoked tobacco. It is worth mentioning that the sum of all the components of a single family presents a lower yield than nicotine alone. The families ordered by decreasing yields are aliphatics, phenols, followed by pyridines, carbonyls, epoxies and polyaromatics. RYO tobaccos present larger yields of aliphatic compounds and pyridine derivatives, while MC tobaccos show higher yields of phenolic compounds (except D and E MC) and carbonyls. The yield of the other families is similar for both tobaccos. MC tobaccos show a higher yield of epoxies whereas RYO tobaccos yield more PAHs than the corresponding counterpart brands. 


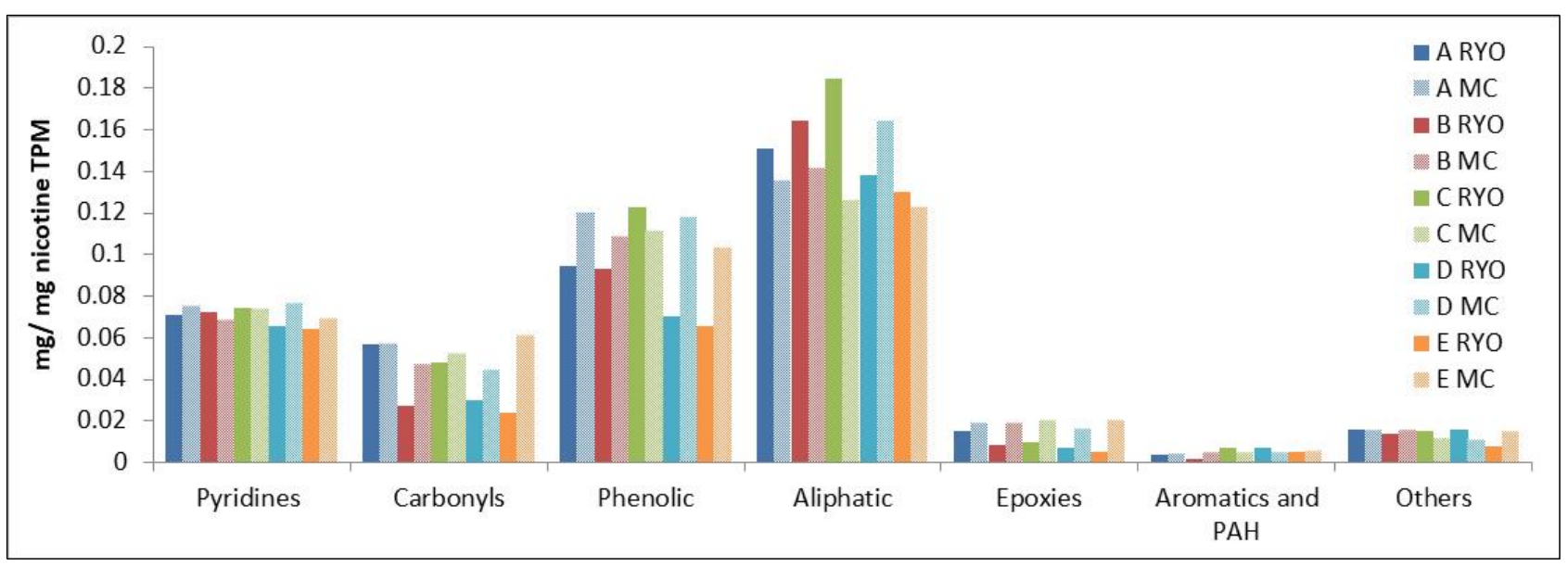

Figure 5. Yields of the different families of compounds for MC and RYO tobaccos

\section{Conclusions}

The amount of tobacco per cigarette required to fill a tube, in general, is higher for the RYO tobaccos than for the cigarette tobacco variety, which is in accordance with the physical characteristics of the tobacco threads. Consequently, the amount of smoked tobacco per cigarette when using the same tubes and under the same smoking regime is higher in the case of RYO tobaccos.

RYO tobaccos show a yield in TPM of around 18-22 $\mathrm{mg} / \mathrm{g}$ of smoked tobacco, while MC tobaccos show lower values, $13-17 \mathrm{mg} / \mathrm{g}$ of smoked tobacco. Consequently, higher amounts of condensable products would be inhaled by the smoker in the case of RYO tobacco, if smoking the same amount of tobacco.

$\mathrm{RYO}$ tobaccos produce much higher amounts of $\mathrm{CO}$ than those provided by the cigarette tobaccos. Only B-MC and $\mathrm{D}-\mathrm{MC}$ tobaccos present a yield of $\mathrm{CO}$ within the 10 $\mathrm{mg}$ /cigarette regulation. Nevertheless, MC tobaccos produce higher yields of other components of the gas fraction than the same brand of RYO tobacco, with the exception of brand $\mathrm{B}$.

Nicotine is by far the major component of the TPM and presents amounts ranging between 2.1 to $3.1 \mathrm{mg} / \mathrm{g}$ of smoked tobacco in the case of RYO presentations and 1.5 to $2 \mathrm{mg} / \mathrm{g}$ of smoked tobacco in the case of MC tobaccos. These values show that none of the brands, for both RYO tobaccos, would comply with current regulations if smoked under these conditions Only B-MC would be within the limits allowed although all other brands show values close to the standard.

The analysis of condensed fraction shows that the yield for RYO tobacco is higher than that for MC tobacco. The principal compounds obtained in this fraction were aliphatics, phenolics, pyridines and carbonyls. RYO tobaccos provide more aliphatic compounds, pyridine derivatives and $\mathrm{PAH}$ than $\mathrm{MC}$ tobaccos. Epoxies are produced in a larger amount in MC than in RYO tobaccos, while phenols and carbonyls depend on the brand more than on the tobacco type.
It can be concluded that RYO tobaccos yield much higher amounts of most of the compounds analyzed than $\mathrm{MC}$ tobaccos and although the analysis of the individual toxicity of the singular compounds has to be taken into account, RYO cannot be considered at all as less harmful than MC.

\section{Acknowledgements}

Financial support for this investigation has been provided by the Spanish Ministerio de Economía, Industria y Competitividad (CTQ2015-70726/P), and the Generalitat Valenciana (PROMETEO2016/056).

\section{REFERENCES}

[1] World Health Organization, WHO Framework Convention on Tobacco Control http://www.who.int/es/

[2] Directiva 2001/37/CE del Parlamento Europeo y del Consejo. Aproximación de las disposiciones legales, reglamentarias y administrativas de los Estados miembros en materia de fabricación, presentación y venta de los productos del tabaco, 2001

[3] T. Castaño, C. Hebert, M ${ }^{\mathrm{a}}$ T. Campo, M. Ysa, A. Pons. Tabaco de liar: una prioridad de salud pública y consumo. Gaceta Sanitari, 26(3), 267-269, 2012

[4] M. Laugesen, M. Epton, M. Chris, M.A. Frampton, M. Glover, R.A. Lea. Hand rolled cigarette smoking patterns compared with factory-made cigarettes smoking in New Zealand men. BMC Public Health, 9, 194-199, 2009

[5] J. Granda-Orive, C. Jiménez-Ruiz. Algunas consideraciones sobre el Tabaco de liar. Archivos de Bronconeumología, 47(9), 425-426, 2011

[6] T. Adam, J. McAughey, C. Mocker, C. McGrath, R. Zimmermann. Influence of filter ventilation on the chemical composition of cigarette mainstream smoke. Analytica Chimica Acta, 657, 36-44, 2010 
[7] M.J. Kaiserman, W.S. Rickert. Handmade Cigarettes: It's the Tube That Counts. The American Journal of Public Health, 82 (1), 107-109, 1992

[8] L. Shalab, R. West, A. McNeil. A comparison of exposure to carcinogens among roll-your-own and factory-made-cigarette smokers. Addiction Biology, 14(3), 315-320, 2009

[9] K.G. Darrall and J.A. Figgins. Roll-your-own smoke yields: theoretical and practical aspects. Tobacco Control, 7, 168-175, 1998.

[10] Comisionado para el Mercado de tabacos. http://www.cmtabacos.es/

[11] Centers for Disease Control and Prevention. Consumption of Cigarettes and Combustible Tobacco-United States, 20002011. Morbidity and Mortality Weekly Report, 61(30), $565-569,2012$

[12] S. Dagnin, A. Stoilova, I. Ivanoc, S. Nikolova. The Effect of Cigarette Design on the Content of Phenols in Mainstream, Tobacco smoke. Beitr Tabakforsch Int. 24(4), 87-193, 2010.

[13] M.J. Oldham, H.J. Haussmann, W. Gommc, L.T. Rimmer, M.J. Morton, W.J. McKinney. Discriminatory power of standard toxicity assays used to evaluate ingredients added to cigarettes. Reg Tox Pharm. 62 (1), 49-61, 2012.

[14] A. Marcilla, I. Martínez, D. Berenguer, A. Gómez-Siurana, M.I. Beltrán. Comparative study of the main characteristics and composition of the mainstream smoke of ten cigarette brands sold in Spain. Food Chem. Toxicol. 50 (5), 13171333,2012

[15] Directive 2014/40/EU of the European parliament and of the council, 2014. Official Journal of the European Union, L $127 / 13,2014$

[16] R. Kumar, S. Prakash, A.S. Kushwah, V.K. Vijayan. Breathe Carbon monoxide concentration in cigarette and Bid smokers in India. Indian Journal of Chest Diseases \& Allied Sciences, 52, 19-24, 2010

[17] N. Djulancic, V. Radojicic, M. Srbinovska. The influence of tobacco blend composition on carbon monoxide formation in mainstream cigarette smoke. Archives of Industrial Hygiene and Toxicology, 64, 107-113, 2013

[18] A. Marcilla, A. Gómez-Siurana, D. Berenguer, I. Martínez-Castellanos, M.I. Beltrán. Reduction of tobacco smoke components yields by zeolites and synthesized Al-MCM-41. Microporous and Mesoporous Materials, 161(1), 14-24, 2012. 